\title{
Assessing the role of ammonia in sulfur transformation and deposition in China
}

\author{
Jiannong Quan*, Xiaoshan Zhang \\ Research Center for Eco-Environment Science, Chinese Academy of Science, Beijing, 100085, PR China
}

Received 3 May 2007; received in revised form 2 October 2007; accepted 2 October 2007

\begin{abstract}
Inorganic thermodynamic equilibrium model (ISORROPIA) coupled with the Models-3 Community Multi-scale Air Quality modeling system (CMAQ) was used to understand the role of ammonia $\left(\mathrm{NH}_{3}\right)$ in sulfur dioxide $\left(\mathrm{SO}_{2}\right)$ transformation and sulfur (S) deposition in China.

The simulated $\mathrm{S}$ and nitrogen $(\mathrm{N})$ compounds in gas $\left(\mathrm{SO}_{2}, \mathrm{NH}_{3}\right)$ and aerosol (sulfate $\left(\mathrm{SO}_{4}^{2-}\right)$, ammonium $\left(\mathrm{NH}_{4}^{+}\right)$) phases and wet deposition were compared against observations at two non-urban sites: Tie Shan Ping (TSP) and Cai Jia Tang (CJT). Observations showed that $\mathrm{SO}_{4}^{2-}$ was the predominant anion in aerosol and precipitation at the sites, and there were not enough $\mathrm{NH}_{3}$ and alkaline dusts (i.e. mineral oxides and carbonates) to neutralize all acidity. Most of the $\mathrm{NH}_{4}^{+}$was therefore probably bound to $\mathrm{SO}_{4}^{2-}$.

The presence of $\mathrm{NH}_{3}$ significantly altered the regional distributions of $\mathrm{S}$ compounds in gas and aerosol phases. Model simulations showed $\mathrm{SO}_{4}^{2-}$ concentration increased by $10-15 \%$ while $\mathrm{SO}_{2}$ concentration decreased by $10-60 \%$ over polluted regions due to $\mathrm{NH}_{3}$. Furthermore, the presence of $\mathrm{NH}_{3}$ enhanced long-range $\mathrm{S}$ transportation for the longer lifetime of sulfate than of $\mathrm{SO}_{2}$ in the atmosphere. $\mathrm{S}$ deposition thereby decreased by $10-30 \%$ over polluted regions.
\end{abstract}

(C) 2007 Elsevier B.V. All rights reserved.

\section{Introduction}

In China, coal accounts for about $70 \%$ of the energy production (CESY, 2005), which leads to large emissions of $\mathrm{SO}_{2}$ (SEPA, 2004). Part of $\mathrm{SO}_{2}$ can be converted to $\mathrm{SO}_{4}^{2-}$ through gas phase or multiphase reactions in the atmosphere, and results in $\mathrm{SO}_{4}^{2-}$ as the predominant anion in aerosol and precipitation in China (Aas et al., 2007). The amounts of $\mathrm{NH}_{3}$, mineral oxides and carbonates dusts are not sufficient to neutralize all acidity over

\footnotetext{
* Corresponding author. Tel.: +86 10 62849117; fax: +86 10 62923563.

E-mail address: quanjn1975@gmail.com (J. Quan).
}

large regions of China, allowing for acid rain to prevail especially in the southern parts of the country (i.e. south of Yangtze River).

$\mathrm{SO}_{2}$ and $\mathrm{NH}_{3}$ are primary pollutants playing important roles in aerosol processes and influencing the acidity of precipitation (Dentener and Crutzen, 1994). Sulfate is mainly produced from the oxidation of $\mathrm{SO}_{2}$, and $\mathrm{NH}_{3}$ plays an important role in this process (Coffman and Hegg, 1995; Ally et al., 2001; Colberg et al., 2000). $\mathrm{NH}_{3}$ reacts with $\mathrm{H}_{2} \mathrm{SO}_{4}$ to form stable ammonium sulfate that is mainly confined to the fine aerosol fraction (Lestaria et al., 2003; Yao et al., 2003; Metzger et al., 2006). Although the mechanism for the formation of ammonium sulfate is still unclear, the prevailing 
hypothesis is that this aerosol fraction may be the result of cloud formation and evaporation cycles (Pandis et al., 1995). Cloud formation allows the heterogeneous oxidation of $\mathrm{SO}_{2}$ to form $\mathrm{H}_{2} \mathrm{SO}_{4}$ in the cloud droplets, which then reacts with $\mathrm{NH}_{3}$ that might exist in the cloud droplets. The lifetime of sulfate in the atmosphere is about a week, which is much longer than that of $\mathrm{SO}_{2}$ (Rodhe et al., 1981; Roelofs et al., 1998). Both the distribution and deposition of $\mathrm{SO}_{2}$ and sulfate are probably influenced by the presence of $\mathrm{NH}_{3}$.

In the past two decades, numerous inorganic thermodynamic equilibrium models have been developed to calculate aerosol composition (e.g., ADDEM (Topping et al., 2005a,b), AIM (Clegg and Pitzer, 1992; Clegg et al., 1998a,b), AIM2 (Wexler and Clegg, 2002), EQSAM (Metzger, 2000; Metzger et al., 2002a,b), EQSAM2 (Trebs et al., 2005; Metzger et al., 2006), EQSAM3 (Metzger and Lelieveld, 2007), EQUISOLV (Jacobson et al., 1996), EQUISOLVII (Jacobson, 1999), GFEMN (Ansari and Pandis, 1999), HETV (Makar et al., 2003), ISORROPIA (Nenes et al., 1998; Pilinis et al., 2000), ISORROPIA2 (Fountoukis and Nenes, 2007), MARS-A (Binkowski and Shankar, 1995), MESA (Zaveri et al., 2005a,b), SCAPE (Kim et al., 1993a,b; Kim and Seinfeld, 1995), SCAPE2 (Meng et al., 1995), UHAERO (Amundson et al., 2006)). Some of them were implemented in global models for simulating aerosol distributions (Metzger, 2000; Jacobson, 2001; Metzger et al., 2002b; Liao et al., 2003; Martin et al., 2004; Rodriguez and Dabdub, 2004; Feng and Penner, 2005; Liao and Seinfeld, 2005; Liao et al., 2006; Tsigaridis et al., 2006; Bauer et al., 2007a,b; Luo et al., 2007). In China, both emissions of $\mathrm{SO}_{2}$ and $\mathrm{NH}_{3}$ are very large (Streets et al., 2003), $\mathrm{SO}_{4}^{2-}$ and $\mathrm{NH}_{4}^{+}$have been found to be the main components in airborne particles (Aas et al., 2007). The interaction of $\mathrm{SO}_{2}$ and $\mathrm{NH}_{3}$ may be especially important to secondary aerosol formation and acid rain in China.

To understand the role of $\mathrm{NH}_{3}$ in $\mathrm{SO}_{2}$ transformation and $\mathrm{S}$ deposition in China, we simulated the distribution and deposition of $\mathrm{SO}_{2}, \mathrm{SO}_{4}^{2-}$ with and without $\mathrm{NH}_{3}$ interactions in this study by an inorganic thermodynamic equilibrium model (ISORROPIA; Nenes et al., 1998) coupled with a three-dimensional chemical transport model (CMAQ; Byun and Ching, 1999).

\section{Model description}

The Models-3 Community Multi-scale Air Quality modeling system (CMAQ; Byun and Ching, 1999) with an embedded inorganic thermodynamic equilibrium model ISORROPIA (Nenes et al., 1998) was used in this study. CMAQ is an Eulerian-type model developed by the U.S. Environmental Protection Agency to address tropospheric ozone, acid deposition, visibility, particulate matter and other pollutants issues in the context of a "one atmosphere" perspective. The applied current version of CMAQ is configured with fourth of the carbon-bond mechanisms (CB-IV; Gery et al., 1989), including 36 species and 96 reactions of which 11 are photolytic. The current cloud scheme in CMAQ is derived from the diagnostic cloud model in RADM Version 2.6 (Walcek and Taylor, 1986; Chang et al., 1990; Dennis et al., 1993). Pollutant scavenging is calculated by two methods depending upon whether the pollutant participates in the cloud water chemistry or on the liquid water content. For those pollutants that participate in the cloud chemistry (and provided that the liquid water content is $>0.01 \mathrm{~g} \mathrm{~m}^{-3}$ ), the amount of scavenging depends on Henry's law constants, dissociation constants, and cloud water $\mathrm{pH}$. For pollutants that do not participate in the aqueous chemistry (or for all pollutants when the liquid water content is below $0.01 \mathrm{~g} \mathrm{~m}^{-3}$ ), the model uses the Henry's Law equilibrium equation to calculate ending concentration and deposition amounts (Roselle and Binkowski, 1999). Dry deposition of gases and aerosols is calculated with a resistance-in-series scheme (Wesely and Hicks, 1977). The three-dimensional meteorological fields used in this study are provided by the Fifth-Generation NCAR/Penn State Mesoscale Model (MM5; Dudhia et al., 1998). The three-dimensional meteorological fields for MM5 were obtained from the European Center for MediumRange Weather Forecasts (ECMWF) analyzed datasets, and were available every $6 \mathrm{~h}$ with $1^{\circ} \times 1^{\circ}$ resolution.

The aerosol systems of ammonium and sulfate are calculated by the ISORROPIA model (Nenes et al., 1998) which estimates gas-aerosol partitioning based on thermodynamic equilibrium. Aerosol particles are assumed to be internally mixed, meaning that all particles of same size have the same composition. Since the significant portion of aerosol mass is in diameter size much larger than $0.1 \mu \mathrm{m}$, the Kelvin effect is neglected (Bassett and Seinfeld, 1984).

Anthropogenic emissions of $\mathrm{SO}_{2}$ used in the CMAQ model are obtained from the Chinese Research Academy of Environmental Sciences (CRAES). These data are provided as $1^{\circ} \times 1^{\circ}$ grid area sources in addition to 1800 coal-fired power plants point sources. Natural and anthropogenic emissions of $\mathrm{NH}_{3}$ and other pollutants (including nitrogen oxides (NOx), carbon monoxide, VOCs etc.) come from the emission inventory on a $1^{\circ} \times 1^{\circ}$ grid specially prepared by the Center for Global and Regional Environmental Research at the University of Iowa 
(Streets et al., 2003) for the TRACE-P (Transport and Chemical Evolution over the Pacific) and ACE-Asia (Aerosol Characterization Experiment in Asia) projects. VOCs emissions were apportioned appropriately among lumped-carbon categories used in CB-IV.

The model domain for CMAQ is $5427 \times 4455 \mathrm{~km}^{2}$, with $81 \mathrm{~km}$ mesh, centered at $\left(36^{\circ} \mathrm{N}, 105^{\circ} \mathrm{E}\right)$. MM5 has 23 vertical layers in the $\sigma_{z}$ coordinates system unequally spaced from the ground to $\sim 23 \mathrm{~km}$. About 9 of these layers are concentrated in the lowest $2 \mathrm{~km}$ of the atmosphere in order to resolve the planetary boundary layer. The CMAQ has 12 levels, with the lowest 7 layers being the same as those used in MM5.

\section{Results and discussion}

Air qualities along with precipitation chemistry are monitored at two field sites established by the Integrated Monitoring Program on Acidification of Chinese Terrestrial Systems (IMPACTS, 2004). Monitoring data for 2003 (Aas et al., 2007) are used in this study. Tie Shan Ping (TSP) $\left(106^{\circ} 41^{\prime} \mathrm{E}, 2^{\circ} 38^{\prime} \mathrm{N}, 450 \mathrm{~m}\right.$ a.s.1.) is located about $25 \mathrm{~km}$ from the centre of Chongqing city, in the southeast of the Sichuan basin; Cai Jia Tang $(\mathrm{CJT})\left(112^{\circ} 26^{\prime} \mathrm{E}, 27^{\circ} 55^{\prime} \mathrm{N}, 450 \mathrm{~m}\right.$ a.s.l) is located in an agricultural region $130 \mathrm{~km}$ southwest of the Hunan province capital, Changsha. Data on air concentrations of $\mathrm{SO}_{2}, \mathrm{NH}_{3}$, nitric acid $\left(\mathrm{HNO}_{3}\right)$ and the water-soluble species $\left(\mathrm{SO}_{4}^{2-}, \mathrm{NH}_{4}^{+}\right.$, nitrate $\left(\mathrm{NO}_{3}^{-}\right)$, chloride $\left(\mathrm{Cl}^{-}\right)$, and sodium $\left(\mathrm{Na}^{+}\right)$, potassium $\left(\mathrm{K}^{+}\right)$, calcium $\left(\mathrm{Ca}^{2+}\right)$ and magnesium $\left.\left(\mathrm{Mg}^{2+}\right)\right)$ in aerosol and precipitation were used in this study to assess the model results. The sampling and analyzing methods of the fields and laboratories at CJT and TSP are described in detail in IMPACTS (2004). The model simulation period covered the whole year of 2003. Simulation results were averaged to be consistent with the monitoring data.

\subsection{Monitoring data and correlation analysis}

Annual average concentrations of main inorganic components in the air and aerosol observed at two sites are shown in Table 1. Annual mean $\mathrm{SO}_{2}$ concentration in 2003 at TSP is higher than at CJT, while $\mathrm{NH}_{3}$ concentration at TSP is lower than at CJT. $\mathrm{SO}_{2}$ concentration is higher than $\mathrm{NH}_{3}$ concentration at both TSP and CJT. The spatial differences of $\mathrm{SO}_{2}$ and $\mathrm{NH}_{3}$ concentrations between the two sites might be due to their different emission sources. $\mathrm{SO}_{2}$ comes primarily from fossil fuel burning activities (e.g., coal consumption), while $\mathrm{NH}_{3}$ comes generally from agricultural activities (Schlesinger and Hartley, 1992; Zhao and Wang, 1994; ECETOC, 1994; Bouwman et al., 1997). No evident correlation between $\mathrm{SO}_{2}$ and $\mathrm{NH}_{3}$ concentrations in the air at the two sampling sites (Fig. 1) also indicated that the two pollutants were from different emission sources.

$\mathrm{SO}_{4}^{2-}$ is the predominant ion in aerosol and precipitation while the content of sea salt is as expected very low (Tables 1 and 2) at these continental sites. The low $\mathrm{pH}$ in precipitation (Table 2) indicates that the overall deposition is acidic, and that $\mathrm{NH}_{3}$ and alkaline dusts are not sufficient to neutralize all acidity of the deposition at TSP and CJT (see also Vogt et al., 2006 and 2007). Observed $\mathrm{SO}_{4}^{2-}$ and $\mathrm{NH}_{4}^{+}$in aerosol and precipitation at CJT and TSP are very strongly correlated. The correlation coefficients between $\mathrm{SO}_{4}^{2-}$ and $\mathrm{NH}_{4}^{+}$are over 0.8 in aerosol and close to 0.9 in precipitation at both sites (Fig. 1). Most of $\mathrm{NH}_{4}^{+}$is probably associated with $\mathrm{SO}_{4}^{2-}$ since $\mathrm{NO}_{3}^{-}$concentration is relatively low, amounting to only $20 \%$ of the $\mathrm{SO}_{4}^{2-}$ concentration.

\subsection{Comparison between simulations and observations}

Model simulated $\mathrm{S}$ and $\mathrm{N}$ compounds in gas and aerosol phases and wet deposition generally agree well with the observations at TSP and CJT (Figs. 2 and 3). Correlation coefficients between simulated and observed values are given in Table 3. It should be mentioned that ISORROPIA is limited to the ammonium-sulfatenitrate-sodium-chloride-water system. Alkaline dusts (i.e. base cation oxides and carbonates) and organic acids are therefore not included. Trebs et al. (2005) and Metzger et al. (2006) found that mineral cations and organic acids are important for the gas-aerosol

Table 1

Annual average air and aerosol concentrations at TSP and CJT in 2003

\begin{tabular}{|c|c|c|c|c|c|c|c|c|c|c|c|}
\hline \multirow[t]{2}{*}{ Site } & \multicolumn{3}{|l|}{ Air } & \multicolumn{8}{|l|}{ Aerosol } \\
\hline & $\begin{array}{l}\mathrm{SO}_{2} \\
\left(\mu \mathrm{g} \mathrm{S} \mathrm{m}^{-3}\right)\end{array}$ & $\begin{array}{l}\mathrm{HNO}_{3} \\
\left(\mu \mathrm{g} \mathrm{N} \mathrm{m}^{-3}\right)\end{array}$ & $\begin{array}{l}\mathrm{NH}_{3} \\
\left(\mu \mathrm{g} \mathrm{N} \mathrm{m}^{-3}\right)\end{array}$ & $\begin{array}{l}\mathrm{SO}_{4}^{2-} \\
\left(\mu \mathrm{g} \mathrm{S} \mathrm{m}{ }^{-3}\right)\end{array}$ & $\begin{array}{l}\mathrm{NO}_{3}^{-} \\
\left(\mu \mathrm{g} \mathrm{N} \mathrm{m}^{-3}\right)\end{array}$ & $\begin{array}{l}\mathrm{NH}_{4}^{+} \\
\left(\mu \mathrm{g} \mathrm{N} \mathrm{m}{ }^{-3}\right)\end{array}$ & $\begin{array}{l}\mathrm{Na}^{+} \\
\left(\mu \mathrm{g} \mathrm{m}^{-3}\right)\end{array}$ & $\begin{array}{l}\mathrm{K}^{+} \\
\left(\mu \mathrm{g} \mathrm{m}^{-3}\right)\end{array}$ & $\begin{array}{l}\mathrm{Ca}^{2+} \\
\left(\mu \mathrm{g} \mathrm{m}^{-3}\right)\end{array}$ & $\begin{array}{l}\mathrm{Mg}^{2+} \\
\left(\mu \mathrm{g} \mathrm{m}^{-3}\right)\end{array}$ & $\begin{array}{l}\mathrm{Cl}^{-} \\
\left(\mu \mathrm{g} \mathrm{m}^{-3}\right)\end{array}$ \\
\hline TSP & 20.2 & 0.8 & 2.4 & 7.92 & 1.46 & 4.58 & 0.95 & 3.08 & 3.63 & 0.33 & 0.93 \\
\hline CJT & 10.8 & 0.9 & 3.0 & 5.46 & 0.91 & 3.19 & 0.31 & 1.67 & 1.67 & 0.15 & 0.29 \\
\hline
\end{tabular}

Data except $\mathrm{HNO}_{3}$ and $\mathrm{NH}_{3}$ are from Aas et al. (2007). 

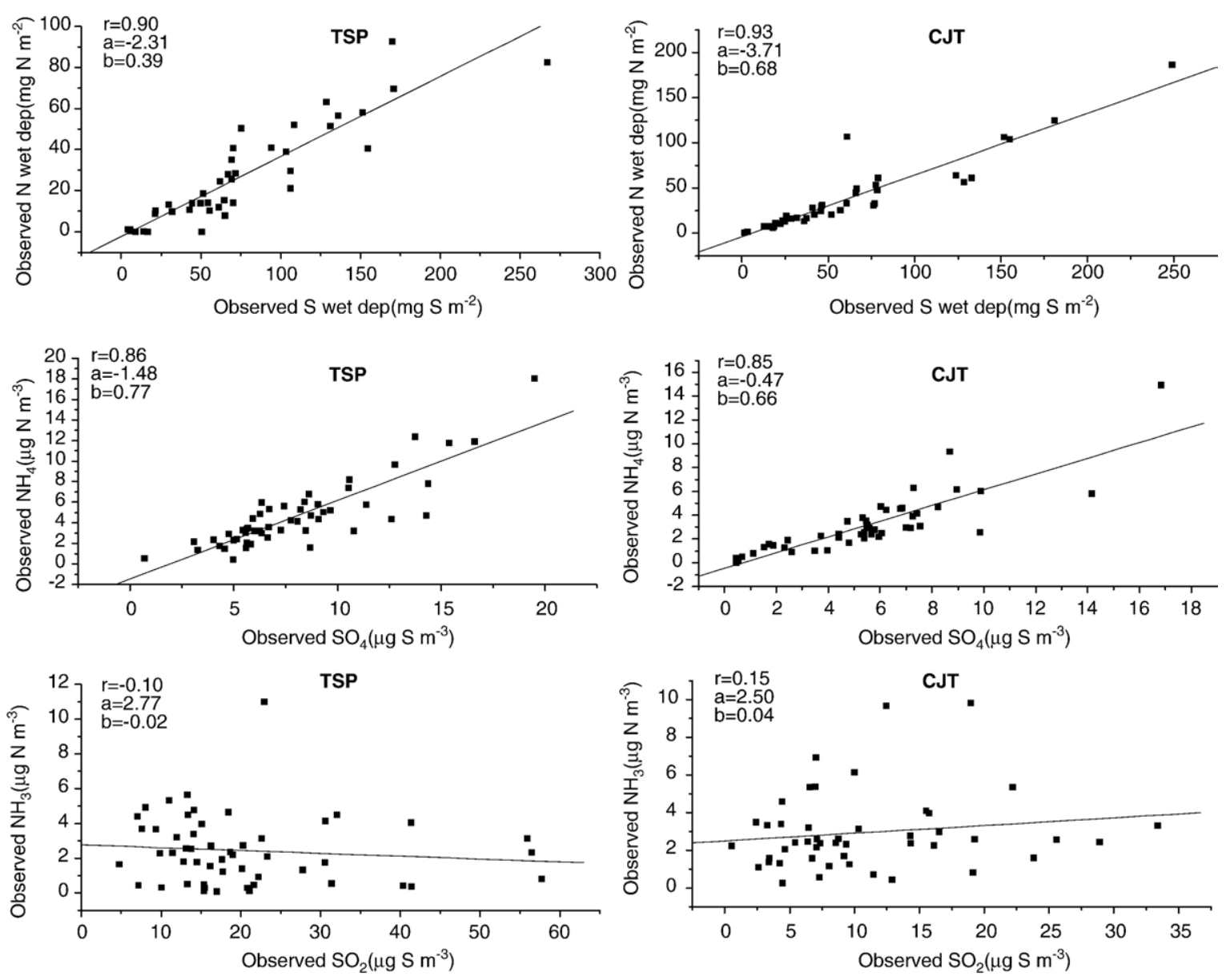

Fig. 1. Correlations of observed $\mathrm{S}$ versus $\mathrm{N}\left(\mathrm{NH}_{4}^{+}\right.$and $\left.\mathrm{NH}_{3}\right)$ wet deposition, $\mathrm{SO}_{4}^{2-}$ versus $\mathrm{NH}_{4}^{+}$concentration, and $\mathrm{SO}_{2}$ versus $\mathrm{NH}_{3}$ concentration at TSP and CJT. Linear correlation coefficient $r$, and best-fit parameters to $y=a+b x$.

partitioning of reactive nitrogen compounds, particularly for the semi-volatile $\mathrm{NH}_{3}$. Therefore, simulated results by using the model of ISORROPIA might pose a potential problem. However, $\mathrm{SO}_{4}^{2-}$ is the dominant anion at TSP and CJT, while the amounts of $\mathrm{NH}_{3}$ and alkaline cations are not sufficient to neutralize all the acidity. Therefore, the contribution of mineral cations and organic acids to the gas-aerosol partitioning of ammonium and $\mathrm{NH}_{3}$ might be not important at TSP and CJT.

Simulated $\mathrm{SO}_{4}^{2-}$ levels in air and $\mathrm{S}$ wet deposition are lower by about 24 and $31 \%$, and 39 and $45 \%$ compared to the observed data at TSP and CJT, respectively (see Table 3). Anthropogenic $\mathrm{SO}_{4}^{2-}$ emissions may be the main reason for the differences between simulations and observations, since all $\mathrm{SO}_{4}^{2-}$ in the model is assumed to be from transformation of $\mathrm{SO}_{2}$. Particles concentrations in the ambient air are still at relatively high level in China due to insufficient controlling measures, in more than half of the cities, for example, annual average concentration of particles $\left(\mathrm{PM}_{10}\right)$ exceeded Grade II $\left(0.1 \mathrm{mg} \mathrm{m}^{-3}\right)$ (SEPA, 2004). The atmospheric particles from the direct anthropogenic emissions (e.g. construction activities and coal consumption) account for large fraction of the total atmospheric particles (Yang et al., 2001), and $\mathrm{SO}_{4}^{2-}$ has been found in these particles from the anthropogenic emissions (Xie et al., 2005).

Correlation coefficients between the simulated and monitored data at TSP are somewhat poorer than at CJT.

Table 2

Annual volume weighted concentrations of main ions in precipitation in 2003 (Aas et al., 2007)

\begin{tabular}{llllllllll}
\hline Site & $\mathrm{pH}$ & $\mathrm{Ca}^{2+}$ & $\mathrm{Mg}^{2+}$ & $\mathrm{Na}^{+}$ & $\mathrm{K}^{+}$ & $\mathrm{NH}_{4}^{+}$ & $\mathrm{SO}_{4}^{2-}$ & $\mathrm{NO}_{3}^{-}$ & $\mathrm{Cl}^{-}$ \\
& & $\mu \mathrm{Eq}$ & $\mu \mathrm{Eq}$ & $\mu \mathrm{Eq}$ & $\mu \mathrm{Eq}$ & $\mu \mathrm{Eq}$ & $\mu \mathrm{Eq}$ & $\mu \mathrm{Eq}$ & $\mu \mathrm{Eq}$ \\
& & $\mathrm{L}^{-1}$ & $\mathrm{~L}^{-1}$ & $\mathrm{~L}^{-1}$ & $\mathrm{~L}^{-1}$ & $\mathrm{~L}^{-1}$ & $\mathrm{~L}^{-1}$ & $\mathrm{~L}^{-1}$ & $\mathrm{~L}^{-1}$ \\
\hline TSP & 4.1 & 58 & 9 & 3 & 8 & 76 & 184 & 35 & 11 \\
$\mathrm{CJT}$ & 4.3 & 60 & 10 & 7 & 10 & 112 & 155 & 60 & 11 \\
\hline
\end{tabular}



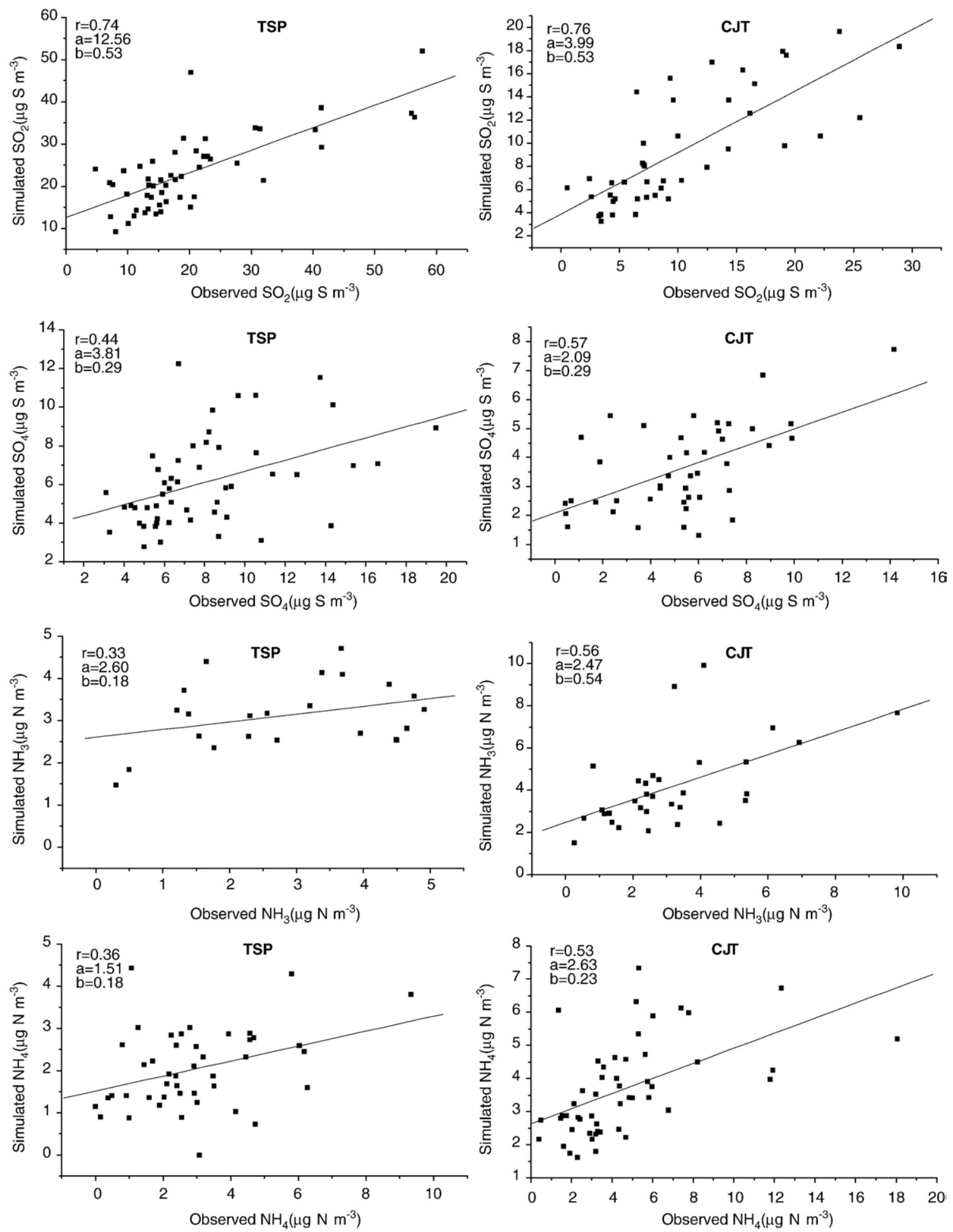

Fig. 2. Model-observation comparisons of $\mathrm{SO}_{2}, \mathrm{NH}_{3}, \mathrm{SO}_{4}^{2-}$ and $\mathrm{NH}_{4}^{+}$at TSP and CJT, statistics parameters are same as in Fig. 1. 

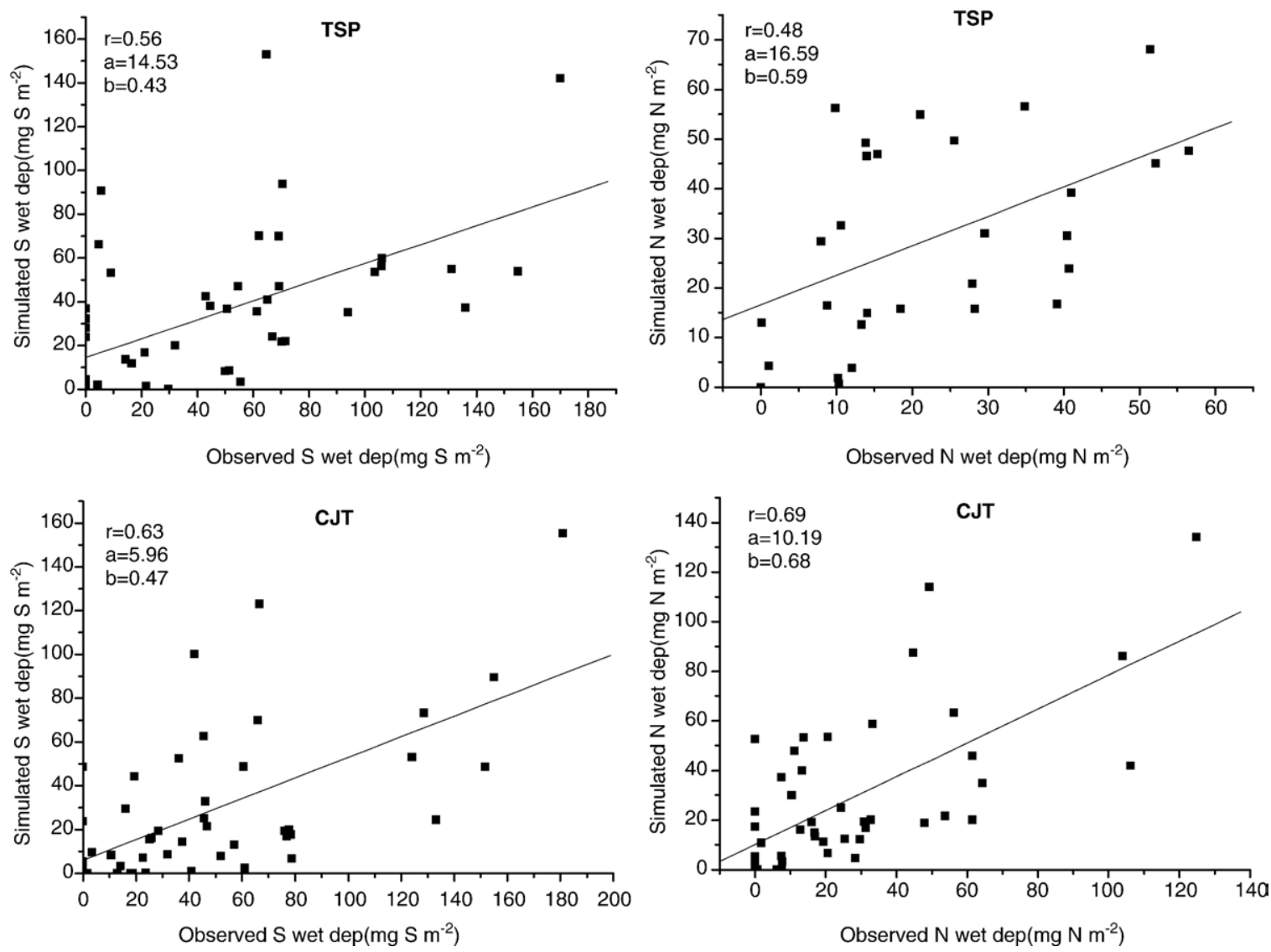

Fig. 3. Model-observation comparisons of S and $\mathrm{N}$ wet deposition at TSP and CJT, statistics parameters are same as in Fig. 1.

For example, the correlation coefficient for ammonia is only 0.33 at TSP while at CJT it is 0.56 . As mentioned above, TSP is located in the vicinity of a major city. Pollution loading at this site is therefore caused by a large number of emission sources that are difficult to estimate, especially for $\mathrm{NH}_{3}$. This uncertainty in estimation of $\mathrm{NH}_{3}$ at TSP is also reflected in a poor simulation of ammonium and its deposition.

\subsection{Distribution of $S$ and $N$ species}

Simulated monthly mean concentrations and depositions of $\mathrm{S}$ species $\left(\mathrm{SO}_{2}\right.$ and $\left.\mathrm{SO}_{4}^{2-}\right)$ and $\mathrm{N}$ species $\left(\mathrm{NH}_{3}\right.$ and $\mathrm{NH}_{4}^{+}$) in July 2003 are depicted in Fig. 4. Regions with high $\mathrm{SO}_{2}$ concentration (up to $20 \mu \mathrm{g} \mathrm{S} \mathrm{m}^{-3}$ ) are located in and around major cities in northern (Beijing), eastern (Shanghai) and southwestern China (Chongqing).

Table 3

Correlations between simulated and observed values

\begin{tabular}{|c|c|c|c|c|c|c|c|c|c|c|c|c|}
\hline & \multicolumn{2}{|c|}{$\mathrm{SO}_{2}\left(\mu \mathrm{g} \mathrm{S} \mathrm{m}^{-3}\right)$} & \multicolumn{2}{|c|}{$\mathrm{SO}_{4}^{2-}\left(\mu \mathrm{g} \mathrm{S} \mathrm{m}^{-3}\right)$} & \multicolumn{2}{|c|}{$\begin{array}{l}\text { S wet deposition } \\
\left(\mathrm{mg} \mathrm{S} \mathrm{m}^{-2} \mathrm{yr}^{-1}\right)\end{array}$} & \multicolumn{2}{|c|}{$\mathrm{NH}_{3} \mu \mathrm{g} \mathrm{N} \mathrm{m}^{-3}$ ) } & \multicolumn{2}{|c|}{$\mathrm{NH}_{4}^{+}\left(\mu \mathrm{g} \mathrm{N} \mathrm{m}^{-3}\right)$} & \multicolumn{2}{|c|}{$\begin{array}{l}\mathrm{N} \text { wet deposition } \\
\left(\mathrm{mg} \mathrm{N} \mathrm{m}^{-2} \mathrm{yr}^{-1}\right)\end{array}$} \\
\hline & TSP & CJT & TSP & CJT & TSP & CJT & TSP & CJT & TSP & CJT & TSP & CJT \\
\hline Observation & 20.16 & 10.77 & 7.92 & 5.46 & 3087 & 2485 & 2.45 & 3.02 & 4.57 & 3.19 & 1106 & 1513 \\
\hline Simulation & 23.14 & 9.32 & 6.13 & 3.62 & 1884 & 1377 & 2.83 & 3.14 & 3.68 & 3.37 & 1536 & 1395 \\
\hline$R$ & 0.74 & 0.76 & 0.44 & 0.56 & 0.56 & 0.63 & 0.33 & 0.56 & 0.36 & 0.53 & 0.48 & 0.67 \\
\hline SD & 6.05 & 3.13 & 2.12 & 1.23 & 28.9 & 22.8 & 0.77 & 1.67 & 0.89 & 1.22 & 17.6 & 22.8 \\
\hline$P$ & $<0.0001$ & $<0.0001$ & 0.00136 & $<0.0001$ & $<0.0001$ & $<0.0001$ & 0.12168 & 0.00092 & 0.01637 & $<0.0001$ & 0.00705 & $<0.0001$ \\
\hline
\end{tabular}

$R$ is correlation coefficient; SD is standard deviations; $P$ is confidence interval. 

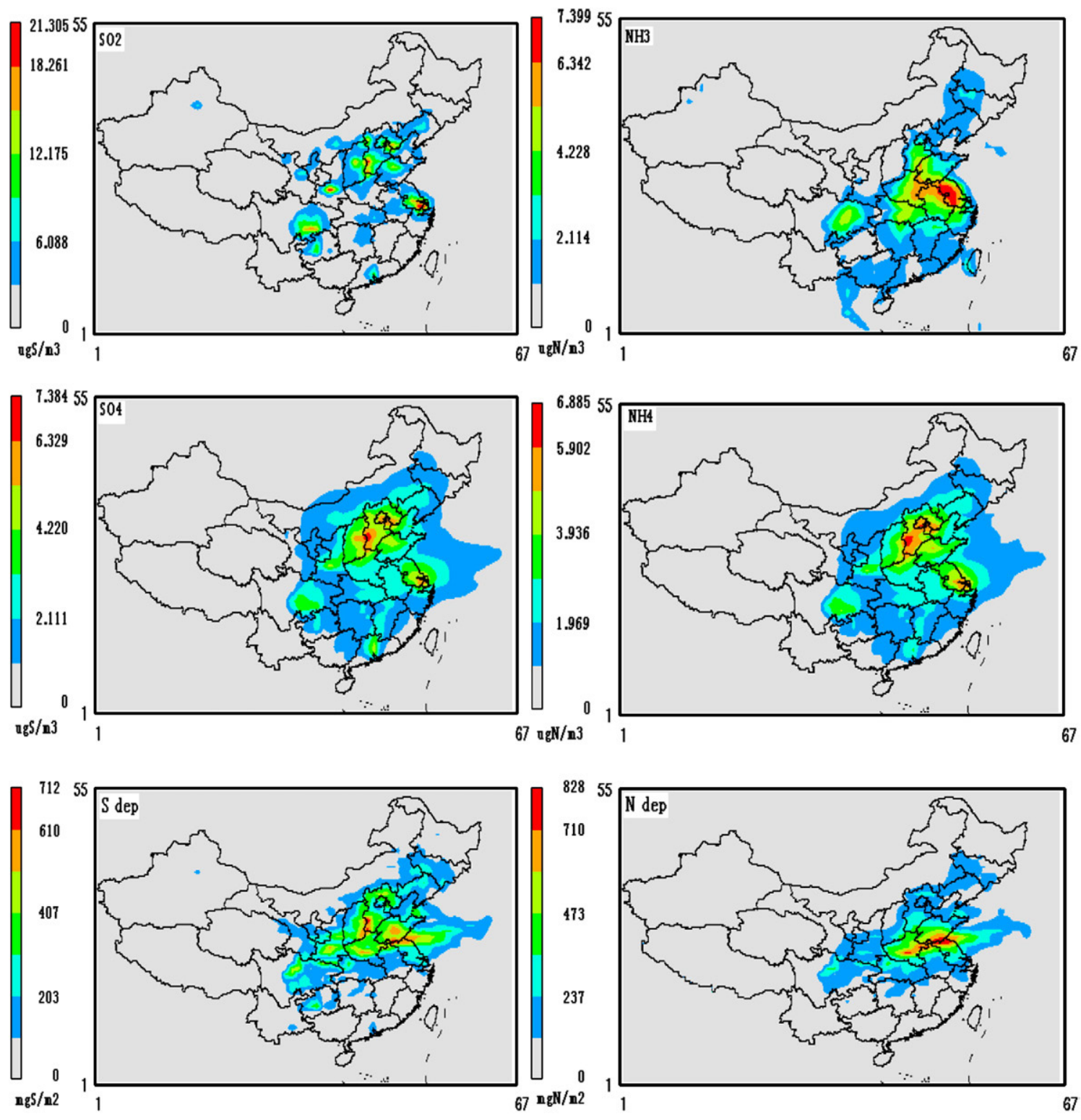

Fig. 4. Distribution of $\mathrm{SO}_{2}, \mathrm{NH}_{3}, \mathrm{SO}_{4}^{2-}$ and $\mathrm{NH}_{4}^{+}$and their deposition in July 2003.

$\mathrm{SO}_{4}^{2-}$ is more widely distributed compared with $\mathrm{SO}_{2}$, due to its longer residual lifetime in the atmosphere. According to the simulations, two regions with high levels of $\mathrm{SO}_{4}^{2-}$ are found: one is in northern China (including Beijing, Hebei and Shanxi) and the other one around Shanghai. Distribution of S deposition is the combined effects of $\mathrm{SO}_{2}$ and $\mathrm{SO}_{4}^{2-}$ pollution levels along with meteorological factors. Regions with high $\mathrm{S}$ deposition are located in northern and eastern China (Fig. 4).

Due to different type of sources, the distribution of $\mathrm{NH}_{3}$ is rather different from that of $\mathrm{SO}_{2}$. Regions with high $\mathrm{NH}_{3}$ concentration are mainly located in eastern China, especially in Jiangsu province, where $\mathrm{NH}_{3}$ concentration is up to $7 \mu \mathrm{g} \mathrm{N} \mathrm{m}{ }^{-3}$. The distribution of $\mathrm{NH}_{4}^{+}$is very similar to that of $\mathrm{SO}_{4}^{2-}$, suggesting the important role of $\mathrm{NH}_{3}$ in governing sulfate levels. The correlation coefficients between simulated $\mathrm{NH}_{4}^{+}$and $\mathrm{SO}_{4}^{2-}$ values are all greater than 0.95 at TSP and CJT, which are consistent with their strong correlations of the observed data (Fig. 1).

\subsection{The role of $\mathrm{NH}_{3}$}

In order to study the effect of $\mathrm{NH}_{3}$ in $\mathrm{SO}_{2}$ transformation and $\mathrm{S}$ deposition, we omitted the $\mathrm{NH}_{3}$ emissions 
in sensitivity experiment. Simulation period is in July 2003. The simulated $\mathrm{SO}_{2}$ and $\mathrm{SO}_{4}^{2-}$ levels and $\mathrm{S}$ deposition with and without $\mathrm{NH}_{3}$ are shown in Fig. 5. Without $\mathrm{NH}_{3}$ emissions, the monthly average $\mathrm{SO}_{4}^{2-}$ concentration decreases by $10-15 \%$, while monthly average $\mathrm{SO}_{2}$ concentration increases by $10-60 \%$ over polluted regions. Likewise, $\mathrm{S}$ deposition increases by $10-30 \%$ over polluted areas due to decreased longrange $\mathrm{S}$ transportation.

The effect of $\mathrm{NH}_{3}$ is likely overestimated since all $\mathrm{NH}_{4}^{+}$is assumed to be bound to $\mathrm{SO}_{4}^{2-}$, while association
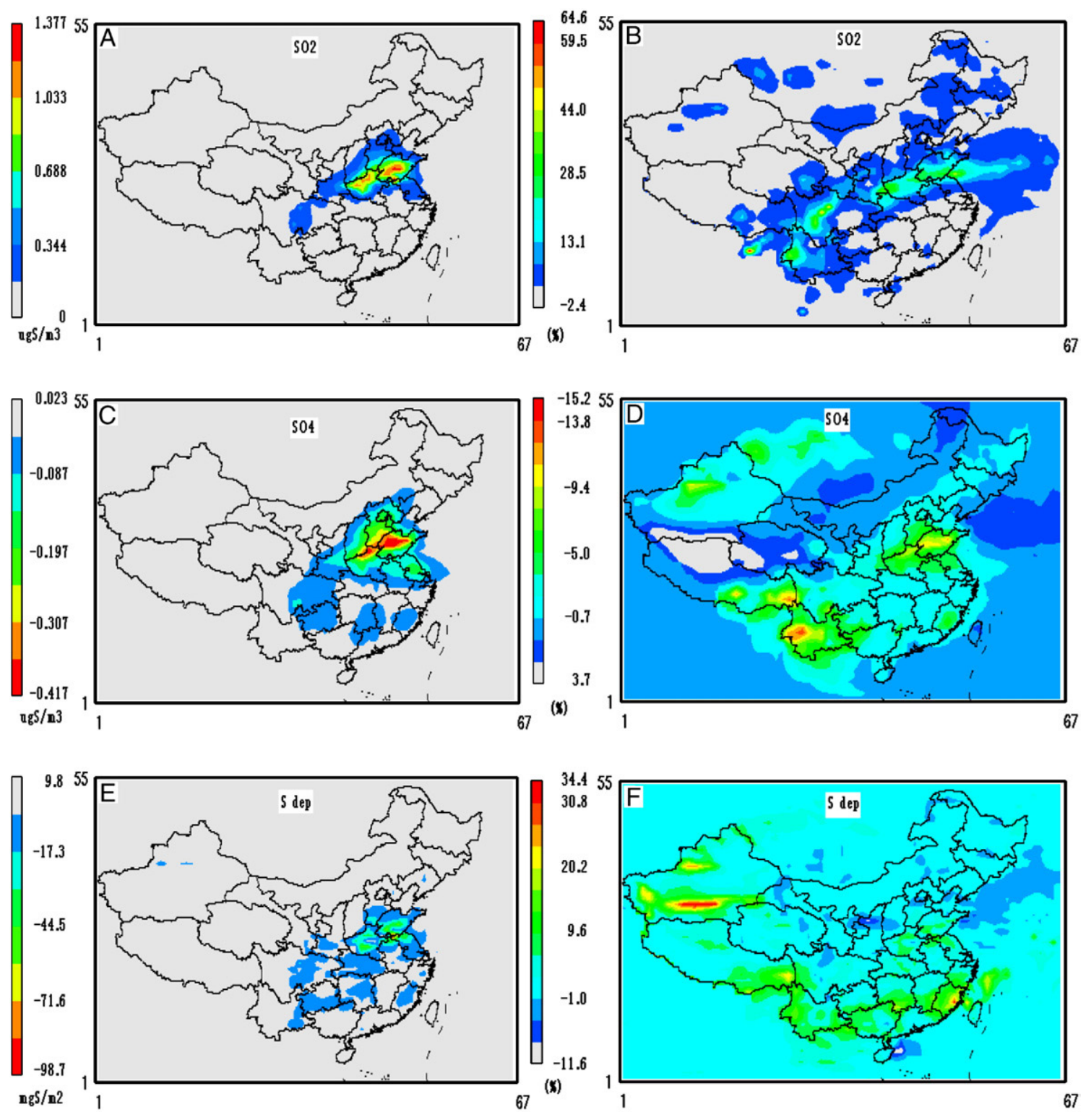

Fig. 5. Differences of $\mathrm{SO}_{2}, \mathrm{SO}_{4}^{2-}$ concentration and $\mathrm{S}$ deposition with and without $\mathrm{NH}_{3}$ interaction in July 2003 (A, C, E represent the difference of $\mathrm{SO}_{2}, \mathrm{SO}_{4}^{2-}$ and $\mathrm{S}$ deposition with and without $\mathrm{NH}_{3}$ emission; $\mathrm{B}, \mathrm{D}, \mathrm{F}$ represent their rate of change). 


\section{Conclusions}

$\mathrm{SO}_{4}^{2-}$ is the predominant anion in aerosol and precipitation at TSP and CJT due to large $\mathrm{SO}_{2}$ emission. The amounts of $\mathrm{NH}_{3}$ and alkaline dusts (i.e. mineral oxides and carbonates) were not sufficient to neutralize all the acidity. Observed $\mathrm{SO}_{4}^{2-}$ and $\mathrm{NH}_{4}^{+}$in aerosol and precipitation at TSP and CJT were strongly correlated. In addition, the concentration of $\mathrm{SO}_{4}^{2-}$ in the atmosphere is much higher than $\mathrm{NO}_{3}^{-}$. Most of the $\mathrm{NH}_{4}^{+}$was therefore probably bound to $\mathrm{SO}_{4}^{2-}$ at TSP and CJT.

Model simulations show that $\mathrm{SO}_{4}^{2-}$ concentration increased by $10-15 \%$ while $\mathrm{SO}_{2}$ concentration decreased by $10-60 \%$ over the most polluted regions due to the role of $\mathrm{NH}_{3}$. S deposition thereby decreased by $10-30 \%$ over polluted areas due to enhanced long-range $\mathrm{S}$ transportation. Therefore the role of $\mathrm{NH}_{3}$ in $\mathrm{SO}_{2}$ transformation and $\mathrm{S}$ deposition could not be neglected in China.

\section{Acknowledgements}

This work was financially supported by Major Project of Chinese National Programs for Fundamental Research and Development (973 Program) (Project number: 2005CB422206). We thank Prof. Yujing Mu for helpful suggestions during preparation of the manuscript. We also thank Prof. Rolf D. Vogt at University of Oslo for his insightful discussions.

\section{References}

Aas, W., Shao, M., Jin, L., Larssen, T., et al., 2007. Air concentrations and wet deposition of major inorganic ions at five non-urban sites in China, 2001-2003. Atmospheric Environment 41, 1706-1716.

Ally, M.R., Clegg, S.L., Braunstein, J., Simonson, J.M., 2001. Activities and osmotic coefficients of tropospheric aerosols: $\left(\mathrm{NH}_{4}\right)_{2} \mathrm{SO}_{4}$ (aq) and $\mathrm{NaCl}(\mathrm{aq})$. The Journal of Chemical Thermodynamics 33, 905-915.

Amundson, N.R., Caboussat, A., He, J.W., Martynenko, A.V., Savarin, V.B., Seinfeld, J.H., Yoo, K.Y., 2006. A new inorganic atmospheric aerosol phase equilibrium model (UHAERO). Atmospheric Chem istry and Physics 6, 975-992.

Ansari, A.S., Pandis, S.N., 1999. Prediction of multicomponent inorganic atmospheric aerosol behavior. Atmospheric Environment 33, 745-757.

Bassett, M., Seinfeld, J.H., 1984. Atmospheric equilibrium model of sulfate and nitrate aerosols-II. Particle size analysis. Atmospheric Environment 18, 1163-1170.

Bauer, S.E., Mishchenko, M.I., Lacis, A.A., Zhang, S., Perlwitz, J., Metzger, S.M., 2007a. Do sulfate and nitrate coatings on mineral dust have important effects on radiative properties and climate modeling? Journal of Geophysical Research 112. doi:10.1029/2005JD006977.

Bauer, S.E., Koch, D., Unger, N., Metzger, S.M., Shindell, D.T., Streets, D.G., 2007b. Nitrate aerosols today and in 2030: importance relative to other aerosol species and tropospheric ozone. Atmospheric Chemistry and Physics Discussions 7, 5553-5593.
Binkowski, F., Shankar, U., 1995. The regional particulate matter model, 1: model description and preliminary results. Journal of Geophysical Research 100 (26), 126-191 209.

Bouwman, A.F., Lee, D.S., Asman, W.A.H., Dentener, F.J., Van der Hoek, K.W., Olivier, J.G.J., 1997. A global high resolution emission inventory for ammonia. Global Biogeochemical Cycles 11, 561-587.

Byun, D.W., Ching, J.K., 1999. Science Algorithm of the EPA Models-3 Community Multiscale Air Quality (CMAQ) Modeling System. EPA/ 600/R-99/030. US Environmental Protection Agency, US Government Printing Office, Washington, DC.

CESY, 2005. China Energy Statistical Yearbook in 2005. China Statistics Press, Beijing.

Chang, J.S., Middleton, P.B., Stockwell, W.R., et al., 1990. The regional acid deposition model and engineering model, acidic deposition: State of Science and Technology, Report 4. National Acid Precipitation Assessment Program.

Clegg, S.L., Pitzer, K.S., 1992. Thermodynamics of multicomponent, miscible, ionic solutions: generalized equations for symmetrical electrolytes. Journal of Physical Chemistry 96 (8), 3513-3520.

Clegg, S.L., Brimblecombe, P., Wexler, A.S., 1998a. Thermodynamic model of the system $\mathrm{H}^{+}-\mathrm{NH}_{4}^{+}-\mathrm{SO}_{4}^{2-}-\mathrm{NO}_{3}^{-}-\mathrm{H}_{2} \mathrm{O}$ at tropospheric temperatures. Journal of Physical Chemistry 102 (12), 2137-2154.

Clegg, S.L., Brimblecombe, P., Wexler, A.S., 1998b. Thermodynamic model of the system $\mathrm{H}^{+}-\mathrm{NH}_{4}^{+}-\mathrm{Na}^{+}-\mathrm{SO}_{4}^{2-} \mathrm{NO}_{3}^{-}-\mathrm{Cl}^{-}-\mathrm{H}_{2} \mathrm{O}$ at 298.15 K. Journal of Physical Chemistry 102 (12), 2155-2171.

Coffman, D.J., Hegg, D., 1995. A preliminary study of the effect of ammonia on particle nucleation in the marine boundary layer. Journal of Geophysical Research 100, 7147-7160.

Colberg, C.A., Krieger, U.K., Peter, T., 2000. Thermodynamic studies of single $\left(\mathrm{NH}_{4}\right)_{2} \mathrm{SO}_{4} / \mathrm{H}_{2} \mathrm{SO}_{4} / \mathrm{H}_{2} \mathrm{O}$ aerosols: atmospheric relevance of letovicite. Journal of Aerosol Science 31 (1), 995-996 Supply.

Dennis, R.L., McHenry, J.N., Barchet, W.R., Binkowski, F.S., Byun, D.W., 1993. Correcting RADM's sulfate underprediction: discovery and correction of model errors and testing the corrections through comparisons against field data. Atmospheric Environment 26, 975-997.

Dentener, F.J., Crutzen, P.J., 1994. A three-dimensional model of the global ammonia cycle. Journal of Atmospheric Chemistry 19, $331-369$.

Dudhia, J., Gill, D., Guo, Y.R., Hansen, D., Manning, K., Wang, W., 1998. PSU/NCAR Mesoscale Modeling System Tutorial Class Notes (MM5 Modeling System Version 2). [Available from the National Center for Atmospheric Research, P. O. Box 3000, Boulder, CO 80307.]

ECETOC(Europe Center for Ecotoxicology and Toxicology of Chemicals), 1994. Ammonia Emissions to Air in Western. ECETOC, Brussels. Technical Report 62.

Feng, Y., Penner, J.E., 2005. Global modeling of nitrate and ammonium: interaction of aerosols and tropospheric chemistry. Journal of Geophysical Research 112. doi:10.1029/2005JD006404.

Fountoukis, C., Nenes, A., 2007. ISORROPIA II: a computationally efficient aerosol thermodynamic equilibrium model for $\mathrm{K}^{+}, \mathrm{Ca}^{2+}$, $\mathrm{Mg}^{2+}, \mathrm{NH}_{4}^{+}, \mathrm{Na}^{+}, \mathrm{SO}_{4}^{2-}, \mathrm{NO}_{3}^{-}, \mathrm{Cl}^{-}, \mathrm{H}_{2} \mathrm{O}$ aerosols. Atmospheric Chemistry and Physics 7, 5263-5274.

Gery, M.W., Whitten, G.Z., Killus, J.P., Dodge, M.C., 1989. A photochemical kinetics mechanism for urban and regional scale computer modeling. Journal of Geophysical Research 94, 12925-12956.

IMPACTS, 2004. Integrated Monitoring Program on Acidification of Chinese Terrestrial Systems, Annual Report, Results 2003. In: Larssen, T., Tang, D. (Eds.), NIVA report no 4905-2004. ISBN: 82-577-4594-4. 
Jacobson, M., 1999. Simulating equilibrium within aerosols and non equilibrium between gases and aerosols. Atmospheric Environment 30, 3635-3649.

Jacobson, M., 2001. Global direct radiative forcing due to multicomponent anthropogenic and natural aerosols. Journal of Geophysical Research 106, 1551-1568.

Jacobson, M., Tabazadeh, A., Turco, R.P., 1996. Simulating equilibrium within aerosols and non-equilibrium between gases and aerosols. Journal of Geophysical Research 101, 9079-9091.

Kim, Y.P., Seinfeld, J.H., 1995. Atmospheric gas-aerosol equilibrium III. Thermodynamics of crustal elements $\mathrm{Ca}^{2+}-\mathrm{K}^{+}-\mathrm{Mg}^{2+}$. Aerosol Science and Technology 22, 93-110.

Kim, Y.P., Seinfeld, J.H., Saxena, P., 1993a. Atmospheric gas/aerosol equilibrium, I. Thermodynamic model. Aerosol Science and Technology 19, 157-181.

Kim, Y.P., Seinfeld, J.H., Saxena, P., 1993b. Atmospheric gas/aerosol equilibrium, II. Analysis of common approximations and activity coefficient calculation methods. Aerosol Science and Technology 19, 182-198.

Lestaria, P., Oskouie, A.K., Noll, K.E., 2003. Size distribution and dry deposition of particulate mass, sulfate and nitrate in an urban area. Atmospheric Environment 37, 2507-2516.

Liao, H., Seinfeld, J.H., 2005. Global impacts of gas-phase chemistry-aerosol interactions on direct radiative forcing by anthropogenic aerosols and ozone. Journal of Geophysical Research 110. doi:10.1029/2005JD005907.

Liao, H., Adams, P.J., Chung, S.H., Seinfeld, J.H., Mickley, L.J., Jacob, D.J., 2003. Interactions between tropospheric chemistry and aerosols in a unified general circulation model. Journal of Geophysical Research 108. doi:10.1029/2001JD001260.

Liao, H., Chen, W.-T., Seinfeld, J.H., 2006. Role of climate change in global predictions of future tropospheric ozone and aerosols. Journal of Geophysical Research 111. doi:10.1029/2005JD006852.

Luo, C., Zender, C.S., Bian, H., Metzger, S., 2007. Role of ammonia chemistry and coarse mode aerosols in global climatological inorganic aerosol distributions. Atmospheric Environment 41, 2510-2533.

Makar, P.A., Bouchét, V.S., Nenes, A., 2003. Inorganic chemistry calculations using HETV - a vectorized solver for the $\mathrm{SO}_{4}^{2-}-$ $\mathrm{NO}_{3}^{-}-\mathrm{NH}_{4}^{+}$system based on ISOROPIA algorithms. Atmospheric Environment 37, 2279-2294.

Martin, S.T., Hung, H.M., Park, R.J., Jacob, D.J., Spurr, R.D., Chance, K., Chin, M., 2004. Effects of the physical state of tropospheric ammonium-sulfate-nitrate particles on global aerosol direct radiative forcing. Atmospheric Chemistry and Physics 4, 183-214.

Meng, Z.Y., Seinfeld, J.H., Saxena, P., Kim, Y.P., 1995. Atmospheric gas-aerosol equilibrium IV thermodynamics of carbonates. Aerosol Science and Technology 23, 131-154.

Metzger, S.M., Lelieveld, J., 2007. Reformulating atmospheric aerosol thermodynamics and hygroscopic growth into fog, haze and clouds. Atmospheric Chemistry and Physics 7, 3163-3193.

Metzger, S.M., Dentener, F.J., Lelieveld, J., Pandis, S.N., 2002a. Gas/ aerosol partitioning I: A computationally efficient model. Journal of Geophysical Research 107. doi:10.1029/2001JD001102.

Metzger, S.M., Dentener, F.J., Jeuken, A., Krol, M., Lelieveld, J., 2002b. Gas/aerosol partitioning II: global modeling results. Journal of Geophysical Research 107. doi:10.1029/2001JD001103.

Metzger, S.M., Mihalopoulos, N., Lelieveld, J., 2006. Importance of mineral cations and organics in gas-aerosol partitioning of reactive nitrogen compounds: case study based on MINOS results. Atmospheric Chemistry and Physics 6, 2549-2567.

Metzger, S.M., 2000. Gas/aerosol partitioning: a simplified method for global modeling. Ph.D. Thesis, University Utrecht, The Nether- lands, ISBN: 90-393-2510-3, http://www.library.uu.nl/digiarchief/ dip/diss/1930853/inhoud.htm, pdf file.

Nenes, A., Pilinis, C., Pandis, S.N., 1998. ISORROPIA: a new thermodynamic model for multiphase multicomponent inorganic aerosols. Aquatic Geochemistry 4, 123-152.

Pandis, S.N., Wexler, A.S., Seinfeld, J.H., 1995. Dynamics of tropospheric aerosols. Journal of Physical Chemistry 99, 9646-9659.

Pilinis, C., Capaldo, K.P., Nenes, A., Pandis, S.N., 2000. MADM-a new multicomponent aerosol dynamics model. Aerosol Science and Technology 32, 482-502.

Rodhe, H., Crutzen, P., Vanderpol, A., 1981. Formation of sulfuric and nitric acid in the atmosphere during long-range transport. Tellus 33, 132-141.

Rodriguez, M.A., Dabdub, D., 2004. A modeling study of size and chemically resolved aerosol thermodynamics in a global chemical transport model. Journal of Geophysical Research 109. doi:10.1029/ 2003JD003639.

Roelofs, G., Lelieveld, J., Ganzeveld, L., 1998. Simulation of global sulfate distribution and the influence on effective cloud drop radii with a coupled photochemistry sulfur cycle mode. Tellus. Series B, Chemical and Physical Meteorology 50, 224-242.

Roselle, S.J., Binkowski, F.S., 1999. Cloud dynamics and chemistry. In: Byun, Ching (Eds.), Science Algorithm of the EPA Models-3 Community Multiscale Air Quality (CMAQ) Modeling System. EPA/600/R-99/030. US Environmental Protection Agency, US Government Printing Office, Washington, DC.

Schlesinger, W.H., Hartley, A.E., 1992. A global budget for atmospheric $\mathrm{NH}_{3}$. Biogeochemistry 15, 191.

SEPA, 2004. Report on the State of the Environment in China 2003. www.zhb.gov.cn/english/SOE/soechina 2003.

Streets, D.G., Bond, T.C., Carmichael, G.R., Fernandes, S.D., Fu, Q., He, D., Klimont, Z., Nelson, S.M., Tsai, N.Y., Wang, M.Q., Woo, J.H., Yarber, K.F., 2003. An inventory of gaseous and primary aerosol emissions in Asia in the year 2000. Journal of Geophysical Research 108 (D21), 8809.

Topping, D.O., McFiggans, G.B., Coe, H., 2005a. A curved multicomponent aerosol hygroscopicity model framework: Part 1 inorganic compounds. Atmospheric Chemistry and Physics 5, 1205-1222.

Topping, D.O., McFiggans, G.B., Coe, H., 2005b. A curved multicomponent aerosol hygroscopicity model framework: Part 2: including organic compounds. Atmospheric Chemistry and Physics $5,1223-1242$.

Trebs, I., Metzger, S., Meixner, F.X., et al., 2005. The $\mathrm{NH}_{4}^{+}-$ $\mathrm{NO}_{3}^{-}-\mathrm{Cl}^{-}-\mathrm{SO}_{4}^{2-}-\mathrm{H}_{2} \mathrm{O}$ aerosol system and its gas phase precursors at a pasture site in the amazon basin: how relevant are mineral cations and soluble organic acids? Journal of Geophysical Research 110. doi:10.1029/2004JD005478.

Tsigaridis, K., Krol, M., Dentener, F.J., Balkanski, Y., Lathiere, J., Metzger, S., Hauglustaine, D.A., Kanakidou, M., 2006. Change in global aerosol composition since preindustrial times. Atmospheric Chemistry and Physics 6, 5143-5162.

Vogt, R.D., Seip, H.M., Larssen, T., Dawei, Z., Zhang, R., Xiao, J., Luo, J., Zhao, Y., 2006. Potential acidifying capacity of deposition experiences from regions with high $\mathrm{NH}_{4}^{+}$and dry deposition in China. Science of the Total Environment 367 (1), 394-404.

Vogt, R.D., Guo, J., Zhang, X., Zhao, D., Xiang, R., Xiao, J., Luo, J., 2007. Water chemistry in forested acid sensitive sites in sub-tropic Asia receiving acid rain and alkaline dust. Applied Geochemistry $22,1140-1148$.

Walcek, C.J., Taylor, G.R., 1986. A theoretical method for computing vertical distributions of acidity and sulfate production 
within cumulus clouds. Journal of the Atmospheric Sciences 43, 339-355.

Wesely, M.L., Hicks, B.B., 1977. Some factors that affect the deposition rates of sulfur dioxide and similar gases on vegetation. Journal of the Air Pollution Control Association 27, 1110-1116.

Wexler, A.S., Clegg, S.L., 2002. Atmospheric aerosol models for systems including the ions $\mathrm{H}^{+}, \mathrm{NH}_{4}^{+}, \mathrm{Na}^{+}, \mathrm{SO}_{4}^{2-}, \mathrm{NO}_{3}^{-}, \mathrm{Cl}^{-}, \mathrm{Br}^{-}$, and $\mathrm{H}_{2} \mathrm{O}$. Journal of Geophysical Research. 107. doi:10.1029/2001JD000451.

Xie, R.K., Seip, H.M., Leinum, J.R., Winje, T., Xiao, J.S., 2005. Chemical characterization of individual particles (PM10) from ambient air in Guiyang city, China. Science of the Total Environment 343, 261-272.

Yang, S.M., Zhang, D.Y., Chen, G.C., 2001. Analysis on air particles in urban area of Chongqing city. Chongqing Environmental Science 23 (3), 18-21 (in Chinese with English abstract).
Yao, X.H., Lau, A., Fang, M., Chan, C.K., Hu, M., 2003. Size distributions and formation of ionic species in atmospheric particulate pollutants in Beijing, China: 1 inorganic ions. Atmospheric Environment 37, 2991-3000.

Zaveri, R.A., Easter, R.C., Peters, L.K., 2005a. A computationally efficient multicomponent equilibrium solver for aerosols (MESA). Journal of Geophysical Research 110 (D24), 203.

Zaveri, R.A., Easter, R.C., Wexler, A.S., 2005b. A new method for multicomponent activity coefficients of electrolytes in aqueous atmospheric aerosols. Journal of Geophysical Research 110 (D02), 201.

Zhao, D., Wang, A., 1994. Emission of anthropogenic ammonia emission in Asia. Atmospheric Environment 28, 689-694. 